University of St. Thomas, Minnesota

UST Research Online

2012

\title{
The Role of Structural and Planning Autonomy in the Performance of Internal Corporate Ventures
}

Kevin L. Johnson

University of St. Thomas, Minnesota, John5258@StThomas.edu

Follow this and additional works at: https://ir.stthomas.edu/ocbmgmtpub

Part of the Business Administration, Management, and Operations Commons

This Article is brought to you for free and open access by the Management at UST Research Online. It has been accepted for inclusion in Management Faculty Publications by an authorized administrator of UST Research Online. For more information, please contact asle4660@stthomas.edu. 


\title{
The Role of Structural and Planning Autonomy in the Performance of Internal Corporate Ventures
}

\author{
by Kevin L. Johnson
}

Historically, autonomy has been treated as a broad one-dimensional construct. This paper proposes that there are two major types of autonomy for internal corporate ventures (ICVs)_planning autonomy and structural autonomy-and examines their respective impact on performance. Little prior knowledge exists regarding the autonomy-performance relationship for ICVs despite the billions of dollars of corporate investment in ICVs. In this study, I collect primary data on 38 ICVs at different stages of development from both venture-level and corporate-level managers from over a dozen companies in the U.S. Midwest. I find that a negative relationship exists for planning autonomy regardless of venture stage. However, for venture structural autonomy, a more complex relationship was discovered, which ranged from positive to negative to curvilinear based on the venture's stage of development.

How can an established company create a successful new business? Although many factors come to mind and have become a point of academic debate, given the parent-venture relationship, the issue of autonomy should be among the top candidates. This study provides an empirical contribution to the corporate entrepreneurship literature regarding the role of autonomy which to date has been primarily conceptual in nature.
The success of new products is equated with technical performance, value to customer, and synergy with firm competencies (Henard and Szymanski 2001; Zirger and Maidique 1990). Other than a loose reference regarding management involvement, the examination of autonomy has been limited. Additionally, prior research suffered from three important maladies: (1) common method bias, a long recognized problem that

Kevin L. Johnson is assistant professor of Management in the Opus College of Business at the University of St. Thomas.

Address correspondence to: K. L. Johnson, Management, Opus College of Business, University of St. Thomas, MCH 316, 2115 Summit Avenue, St. Paul, MN 55105-1096, USA. Phone: 651-962-5431. E-mail: john5258@stthomas.edu. 
causes spurious results due to dependent and independent variables obtained together (Campbell and Fiske 1959); (2) extensive sample contamination from related phenomena (discussed in detail later); and (3) ambiguous definitions. Nevertheless, a popular assumption driven by anecdotal evidence and implicit theories regarding the success of an internal corporate venture (ICV) is that the more autonomy, the better. Consequently, research into the autonomyperformance relationship has been inconclusive. The basic research question examined in this study is: Do ICVs designed with more autonomy perform better than those designed with less autonomy?

The major contribution of this study comes from the identification and development of two types of venture autonomy-structural and planningthat are significant to ICV performance. Whereas venture structural autonomy (VSA) represents the extent to which the venture's operations are linked to those of other businesses of the corporation, venture planning autonomy (VPA) represents the extent to which the venture's management team is responsible for establishing goals, timetables, and strategy for the venture. Another major contribution of this study is the first discovery of the complex relationship between ICV performance and VSA.

The motivation to examine ICVs is due to their potential strategic competitiveness for both small and large companies and the lack of understanding of what truly drives ICV performance, as shown by the inconsistency of findings and performance. ICVs are themselves small businesses. Learning from the efforts and mistakes of large established corporations can be crucial to the survival of the independent small business. Furthermore, the necessary capital available to the large corporation (Baysinger and Hoskisson 1989; Gooding and Wagner 1985) to purchase an external venture can be a significant constraint for smaller enterprises. Finally, corporations invest billions of dollars in resources for internal venture development projects even though after years of operations and irrespective of the measures of success (Block 1989; Campbell and Park 2004; Garvin 2002, 2004), 50-99 percent fail to achieve their performance expectations (Birkinshaw 2005; Chesbrough 2000). Yet ICVs continue to be pursued over external ventures because when successful, they represent more innovative growth (Antoncic and Prodan 2008; McCrea and Betts 2008).

\section{Literature Review and Hypotheses}

The Autonomy-Performance Link

Numerous potential contributors to ICV success and failure have been explored (MacMillan, Block, and Subbanarasimha 1986; Sykes and Block 1989) with limited results. Autonomy was first selected for the study variable here because it is one of the four dimensions of ICVs provided by Thornhill and Amit (2001) that is also arguably a distinguishing factor between corporate and traditional entrepreneurship (e.g., ICV managers may be directed by parent corporations, whereas independent entrepreneurs have autonomy over the decision making for their ventures)- the other dimensions are degree of relatedness, extent of innovation, and nature of sponsorship. Autonomy was also selected because it is also a dimension of entrepreneurial orientation (EO) and therefore may be a key factor in venture performance outcomes. A firm with practices and policies designed around entrepreneurship is described as having an entrepreneurial orientation (Lumpkin and Dess 1996). The EO construct includes dimensions of innovativeness, proactiveness, risk taking, competitive aggressiveness, and autonomy (Lyon, Lumpkin, and Dess 2000; Miller 1983; Miller and Friesen 1982), and has been 
attributed to the overall success of some firms (McGrath and MacMillan 2000). Although there have been mixed results regarding a specific relationship between EO and established firm performance (Wiklund and Shepherd 2005), the most recent meta-analytical study still indicates a moderate $(r=0.24)$ relationship (Rauch et al. 2009), which may be a result of the role of autonomy.

This study does not test the EO of an organization but examines the autonomy relationship. Despite recent papers on autonomy versus dependence (Robins, Tallman, and Fladmoe-Lindquist 2002), autonomy in international joint venture decisions (Glaister, Husan, and Buckley 2003), and the issue of control versus autonomy (Paik and Choi 2007), the importance of autonomy on ICV performance has been generally neglected; meanwhile, existing scales "were often limited to measurement of structural autonomy without regard to strategic autonomy" (Lumpkin, Cogliser, and Schneider 2009, p. 53). "[F]rom an EO perspective [autonomy] refers primarily to strategic autonomy" (Lumpkin, Cogliser, and Schneider 2009, p. 50).

In total, virtually by definition, new ICVs represent innovative and proactive behavior. A new ICV is also risky as an unknown (Matthews and Human 2004) but not always autonomous. An ICV is linked to an existing parent with whom the type and level of autonomy may substantially differ; therefore, it is conceivable that autonomy might explain a lot of variance in ICV performance. However, in order to ascertain the autonomy relationship for ICVs, we must clearly distinguish the ICV from related phenomena, thereby addressing an earlier malady.

\section{Related Phenomena-Similar But Not Sufficient}

ICVs exist under the umbrella of corporate entrepreneurship-a broad term that encompasses several different business development activities (Sharma and
Chrisman 1999). A variety of criteria have been used since 1977 to depict the ICVs (see Table 1). In general, a company that internally generates, funds, and develops new businesses utilizing internal resources is directly engaging in internal corporate venturing or the development of ICVs (Burgelman 1983, 1984a, 1984b, 1984c; Campbell et al. 2003; Miles and Covin 2002). In the exploration of internal ventures, researchers have compared small versus large firms (Day 1994; Siegel, Siegel, and Macmillan 1993), independent ventures versus corporate ventures (Simon and Shrader 1997; Zahra 1996), focused on a single industry (McGrath 1995; Zahra and George 1999), and even different countries (Thornhill and Amit 2001). Throughout, the overlap of phenomena is understandable; however, scholars now recognize that managing and developing an ICV is not the same as running an established business, pursuing an external start-up, or even necessarily engaging in traditional product development. This distinction is crucial to the advancement of ICV research.

Product Development. One common overlap with ICVs has been product development and the plethora of studies that exist (Brown and Eisenhardt 1995; Cooper, Edgett, and Kleinschmidt 2001; Gomes et al. 2001; Henard and Szymanski 2001; Ledwith 2000; Simon and Houghton 2003; Storey and Easingwood 1996; Story, Smith, and Saker 2001). Today, scholars acknowledge that a new product is not necessarily the same thing as a new corporate venture (Greene, Brush, and Hart 1999), and that a common problem for corporations has been in the failure to understand the distinctive features of new markets, businesses, products, and so on (Garvin 2002).

Product development is a broad concept that represents both new and existing products. A new product can represent product repositioning, product 


\begin{tabular}{|c|c|}
\hline Present & 1. Originated internally \\
\hline Proposal & $\begin{array}{l}\text { 2. Considered distinct from company's existing products/ } \\
\text { services } \\
\text { 3. Intended as or became a new business } \\
\text { 4. Pursued within past seven years }\end{array}$ \\
\hline $\begin{array}{l}\text { Thornhill and } \\
\text { Amit (2001) }\end{array}$ & $\begin{array}{l}\text { A business was considered new if it had developed any three of } \\
\text { the following: } \\
\text { 1. New markets } \\
\text { 2. New methods of distribution } \\
\text { 3. New products/services } \\
\text { 4. New technology }\end{array}$ \\
\hline $\begin{array}{l}\text { Zahra and } \\
\text { George } \\
\text { (1999) }\end{array}$ & $\begin{array}{l}\text { 1. The firm had to be in existence for eight years or less } \\
\text { 2. The firm had to be headquartered in the United States } \\
\text { 3. The venture had to be active in one or more of the major } \\
\text { areas that constituted the biotechnology industry }\end{array}$ \\
\hline $\begin{array}{r}\text { McGrath } \\
(1995)\end{array}$ & $\begin{array}{l}\text { 1. Attempt to enter a new market } \\
\text { 2. Sell a new product/service } \\
\text { 3. Employ a significantly different process, utilizing internal } \\
\text { resources }\end{array}$ \\
\hline Day (1994) & $\begin{array}{l}\text { 1. Start-up that originated internally } \\
\text { 2. New to firm on at least two dimensions (product, market, } \\
\text { technology) } \\
\text { 3. Requires significant investment of company resources } \\
\text { beyond expenditure year } \\
\text { Includes new products based on new technologies that would } \\
\text { displace a company's existing product. Does not include } \\
\text { product extensions or brand introductions. }\end{array}$ \\
\hline $\begin{array}{l}\text { Miller, } \\
\text { Gartner, } \\
\text { and Wilson } \\
\text { (1988) }\end{array}$ & $\begin{array}{l}\text { A business marketing a service or product that: } \\
\text { 1. The parent company has not previously marketed } \\
\text { 2. That required the parent company to obtain new } \\
\text { equipment, people, or knowledge }\end{array}$ \\
\hline $\begin{array}{l}\text { von Hippel } \\
\text { (1977) }\end{array}$ & $\begin{array}{l}\text { 1. Developing a new product } \\
\text { 2. Bringing it to market } \\
\text { 3. Carrying it through at least it initial phases of marketplace } \\
\text { activity }\end{array}$ \\
\hline
\end{tabular}

line extension, product modifications, a new product category for the firm, or a previously nonexistent product to the world (Cooper, Edgett, and Kleinschmidt 2001; Crawford 1994; Palmer and Cole 1995). Most importantly, scholars have noted that, "this activity [new product development] does not always require the creation of a new organization... a new product launch/market extension vis-à-vis an "innovation" is not the same thing as a new corporate venture" (Greene, Brush, and Hart 1999).

Independent Ventures. It may initially seem logical to equate an ICV to an independent venture (or start-up) given that a new ICV is a start-up within the context 
of the established parent firm. The ICV can have a venture champion and the independent venture has its entrepreneur. However, ICV champions tend to have access to valuable resources and support from existing parent firms. In contrast, the independent entrepreneur lacks the "deep pockets" of a parent organization, but enjoys more decisionmaking freedom without the bureaucracy of a parent organization. It is not until investors demand it that most entrepreneurs even engage in formal strategic planning, compose written business plans, and/or address other hurdles (Hoy 2006).

When Chrisman, Bauerschmidt, and Hofer proposed their model for the performance of independent ventures, they stated that "the determinants of performance of a new [independent] venture and an established business are nearly identical" (emphasis added) (Chrisman, Bauerschmidt, and Hofer 1998). In their model of independent venture performance, their referenced studies included corporate ventures, as well as independent ventures. Similarly, in Sandberg and Hofer's (1987) review of other venture performance studies, we find that many scholars had relied upon the PIMS (Profit Impact of Marketing Strategy) database (that is, product development data), venture capital projects, or independent start-ups (see Table 2, which illustrates this overlap in earlier work). Indeed, many early proclaimed ICV studies combined related phenomena to increase the sample size (but not the representativeness), which likely led to the inconsistency of findings.

\section{External Ventures and Established}

Businesses. A common misperception is that if we understand how to manage and grow established businesses, then we can do the same with ICVs. However, scholars have now revealed that some of the skills, capabilities, policies, and structures that are pertinent to the success of an established business may in fact contribute to the failure of a new business (Block 1982; Campbell et al. 2003; Tushman and Nadler 1986). An ICV can be completely autonomous like an independent start-up, or it can be integrated (like an acquisition) into the parent firm and subjected to the same rules and requirements of the existing business(es). This suggests performance implications for the venture based on the nature or type of venture autonomy. In the next sections, the nature of venture autonomy for this study is discussed and hypotheses are presented.

\section{The Nature of Venture Autonomy}

Autonomy has historically been treated as a one-dimensional construct with inconclusive findings drawn from this broad view (Rauch et al. 2009). It is a unique characteristic of ICVs and prone to implicit theories based on anecdotal evidence and personal experiences. For instance, during interviews, it is not uncommon for respondents to express their belief that more (or less) autonomy is appropriate based on their experiences. In practice, autonomy can reflect many conditions, such as tight versus loose controls, uniform versus tailored policies, and centralized versus decentralized processes, which early research believed to impact the performance of established businesses (Block 1982). As a result, recent researchers now suggest that autonomy may be best examined as a multidimensional construct (Covin and Miles 2007).

A recent study unintentionally reflects two major types of autonomy implicit in the extant literature when the authors suggest that venture units need (1) sufficient separation and (2) to make their own investment decisions (Campbell et al. 2003). First, the authors have indicated what I call the structural type of autonomy that addresses the physical location and/or separation between the 


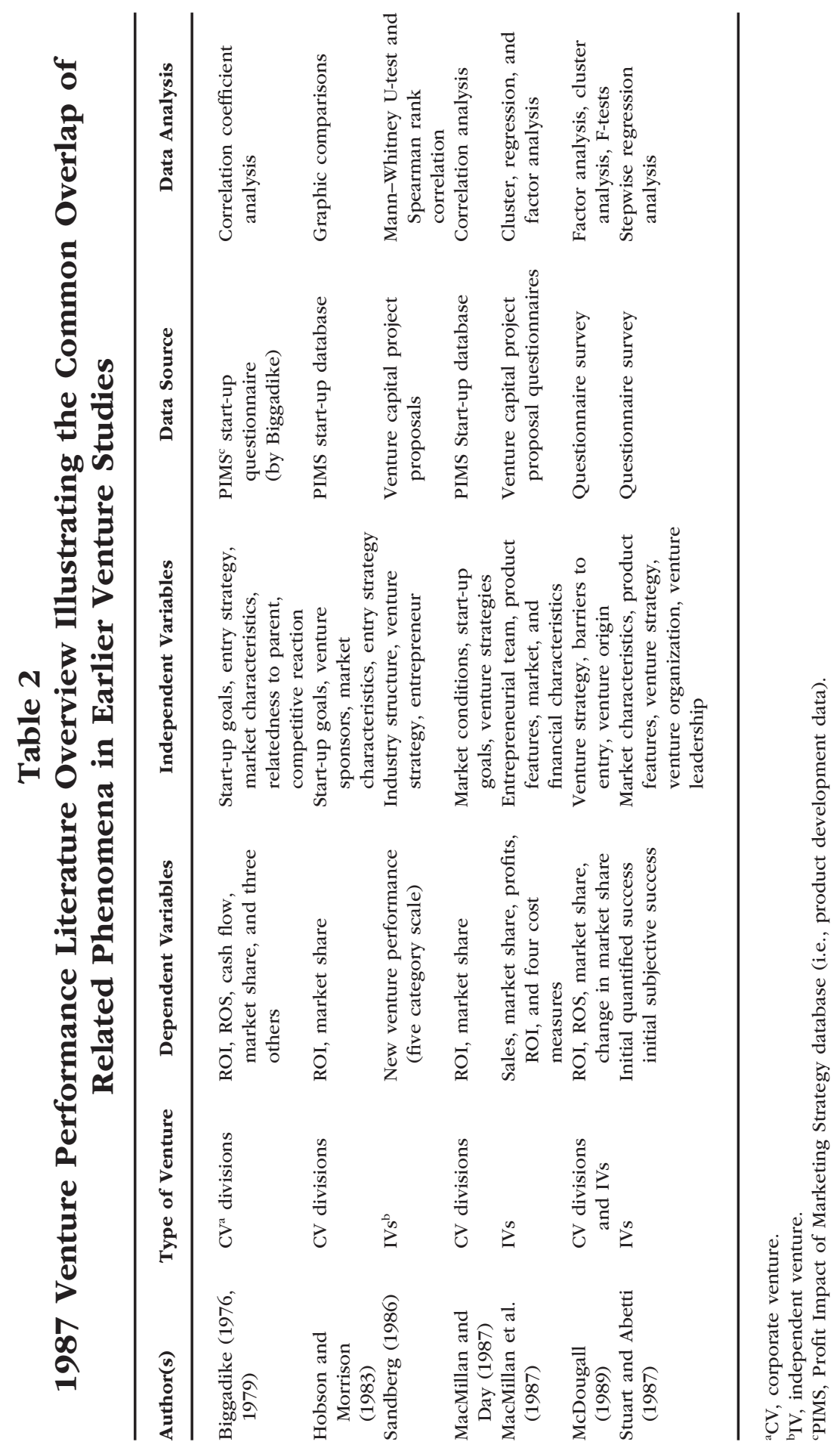


venture and existing business units. Similarly, others have asserted that divisions charged with identifying, launching, and growing promising new businesses internally should do so by "creating protected entrepreneurial islands, with their own distinctive modes of operation, in the midst of the traditional organization's formal structures and processes" (Garvin 2002, p. 9). In other words, "sufficient separation" and "entrepreneurial islands" both suggest that the ventures should be self-contained business units whose operations are independent of the other businesses. Second, the authors indicate what I consider the planning type of autonomy. Planning autonomy addresses the basic ideas of planning and control, such as setting goals, strategy, and evaluating progress.

In this study, I propose these two types (or dimensions) of venture autonomy-VSA and VPA. Together, they reflect the physical and operational links between the venture and the parent, as well as the freedom of the managers to establish the plan for the venture. From an analogous personal perspective, autonomy could reflect whether your office is located at the headquarters or at home; and whether you had the freedom to set your own hours and goals. In turn, your productivity might be impacted by these types and levels of autonomy afforded you in your work.

\section{Venture Autonomy Hypotheses}

Our own experience-based bias favors more autonomy. Given the inconsistency of earlier findings, in this section, we see both the support and nonsupport found in the literature based upon the available sample at the time beginning with the support for planning autonomy.

Planning Autonomy Support. A direct association was found between innovation and the commitment of management, as well as between management attitudes and the establishment of an innovative environment (Karagozoglu 1988; Waters 2000). A strong correlation was also reported between venture performance and parental separation (Birkinshaw, Batenburg, and Murray 2002). The idea was that managers needed to protect the ICV by making it independent of the parent as quickly as possible. Based on observations from the PIMS database, scholars suggested that corporate management should take a "hands-off" approach to ventures (Miller and Camp 1985). Accordingly, research has supported "independent" decisionmaking for new ventures, and attributed the difference between success and failure to management, finding greater success when corporate management stayed out of the way (Birkinshaw, Batenburg, and Murray 2002; Block and MacMillan 1993; Ginsberg and Hay 1994; MacMillan, Block, and Subbanarasimha 1986; Sykes and Block 1989).

Similarly, some scholars have asserted that venture-level managers need to be able to define the rules of the game and direct expectations for their ventures (Ginsberg and Hay 1994). Tidd and Taurins (1999) stated that there is often a conflict between the parent's goals and the venture's activities. Many scholars, even those initially biased toward venture-parent integration, have found support for separating the developing venture from the parent (Birkinshaw, Batenburg, and Murray 2002). In a subsequent study using the PIMS database, Miller, Spann, and Lerner (1991) found that a high level of direct corporate involvement actually reduced performance in terms of both lower product quality and higher costs. The overall implication is more authority for venture management and less intrusion from corporate management. Therefore, we hypothesize:

H1a: The degree of VPA will be positively associated with venture performance. 
Planning Autonomy Nonsupport. The prevailing argument has been to shield the emerging business from the corporate bureaucracy. However, although we believe that venture managers need to be free (from parental distractions) to adapt and modify venture operations as new market information becomes available, the overall objectives and expectations still have to be agreed upon by the parent organization. The venture can also benefit tremendously from the knowledge, experience, and guidance of the parent in much the same way the corporation might benefit from the wisdom of its board of directors. The suggestion that venture managers should have autonomy to define the rules (Ginsberg and Hay 1994) may neglect the experience of senior corporate-level executives, as well as create hostility between venture managers and the managers of existing business units. Management should provide the venture some freedom but must also pre-empt the conflicts that can arise (Tidd and Taurins 1999). Overall, there are no solid reasons to believe venture-level managers will be better equipped to establish a successful venture in the absence of corporate-level input. It is more likely that the more informed the guidance senior executives provide to venture managers, the better the venture will perform.

Finally, given that the parent's assessment ultimately will determine the fate of the venture, it is prudent to have more parental input from the corporate-level executives in the planning process. In essence, the ICV is not linked to the parent (after all, it is a "new" venture), but the parent should remain highly involved in its development. Likewise, the ICV managers should welcome and capitalize on the parental involvement, especially in planning activities and decisions so that performance expectations are agreed upon, realistic, and/or more easily modified, if necessary, as more details of the targeted market of the ICV become available. Thus, the argument is to not give planning autonomy to the venture but to have the planning directly dependent upon the corporate evaluators. Therefore, we hypothesize:

\section{H1b: The degree of VPA will be negatively associated with venture performance.}

Structural Autonomy Support. As noted, a popular assumption is that new ventures need to be free from the standard bureaucratic requirements in order to adapt to changing market demands. Scholars believed that the many corporate policies, procedures, and structures designed to facilitate the management of existing businesses actually impeded the development of new ventures (Luther 1984). Thornberry (2003) pointed out that some companies spin out their ventures so that they will not be constrained by established company policies and protocols. In a study of ventures in four large firms, Dougherty (1995) found that new product ventures that continued to operate within the structure and processes established for existing business units failed. Consequently, the argument is made that ventures should be structurally autonomous. Therefore, we hypothesize:

\section{H2a: The degree of VSA will be positively associated with venture performance.}

Structural Autonomy Nonsupport. In stark contrast to the argument for structural autonomy is the consideration that familiarity, experience, and active sponsors with intimate knowledge of the business may drive venture success. For instance, research has shown that separation bred conflict within many organizations (Birkinshaw, Batenburg, and Murray 2002; Garvin 2002, 2004; Sobkowiak 2002). Similarly, there has been considerable research suggesting that separation does not support venture performance (Birkinshaw, Batenburg, 
and Murray 2002; Campbell et al. 2003; Garvin 2002, 2004; Luther 1984). Given the potential for increased organization conflict and the lack of support specifically for increased venture performance, we hypothesize:

\section{H2b: The degree of VSA will be negatively} associated with venture performance.

\section{Venture Stages of Development}

There are arguments both for and against autonomy. Drawing from the knowledge of independent ventures, we believe that these mixed findings are due to the various stages of development that a venture undergoes over time. As an independent venture develops, what it takes to continue its development also changes (Boeker and Karichalil 2002). Research has supported that organizations do experience stages or phases of development with different emphasis or challenges at different stages (Drazin and Kazanjian 1990; Kazanjian and Drazin 1989, 1990). Extrapolating from these, we expect potential changes in the autonomous needs of an ICV as it develops as well.

For instance, the degree of internal support and other venture needs should change as management's understanding of the venture and its targeted markets increase. Recent research has analyzed the Corporate Entrepreneurship Assessment Instrument (CEAI) used to evaluate the entrepreneurial readiness of corporations (Hornsby, Kuratko, and Zahra 2002) and presented many factors as well as challenges regarding new venture pursuits. Some of the factors presented included the need for internal support (George and MacMillan 1985), knowledge and understanding of competitive markets (Zahra, Neubaum, and El-Hagrassey 2002), and market attractiveness (Chandler and Hanks 1994). Quite possibly, performance expectations and satisfaction would also vary with the venture's stage of development as a function of market feedback. In general, the venture will need individuals with diverse skills (Ensley, Pearson, and Amason 2002), and marketexperienced personnel (Garvin 2002).

Consistent with Thornhill and Amit (2001), we have three stages of venture development: early stage (i.e., year of first financial investment in the venture), middle stage (i.e., year the venture began to generate revenue), and established stage (i.e., year the venture became profitable). Perhaps one of the most critical stages for an independent venture is the early stage (or start-up). It is a stage during which an independent venture must survive on limited start-up capital. During this time, the entrepreneur must acquire customers and enough revenues to support its operations before the start-up capital is depleted. In terms of its structure, we expect the venture to be separated from the existing business so that it may react quickly to market developments without the corporate bureaucracy impeding its growth.

In the early stage of development, the decision to pursue the venture, the budget for the venture, as well as the motivation, style of management, strategies, objectives, and expectations, must be established by the parent and accepted by the venture manager. Many unknowns will also begin to be answered, and the parent needs to monitor the emerging venture as a result. Given the negative association between mature ventures versus the need for parental resources (Thornhill and Amit 2001), once the venture matures into the middle stage, we believe more autonomy may be appropriate. Structurally, once the venture reaches maturity, the parent should remove autonomy and integrate the venture into the existing portfolio of businesses. In summary, the stage of development for the venture will moderate the relationship between 
performance and autonomy. Therefore, we hypothesize:

\section{H3: The relationship between autonomy} and performance will be moderated by the stage of development for the venture.

\section{Research Design}

This research recognizes the trade-offs of early research designs and seeks to improve upon them where possible. Since executives can define their business development activities in terms of corporate venture capital, acquisitions, alliances, product developments, extensions, new products, and so on, without a concise definition, researchers risk obtaining samples that are not representative of the phenomena. Indeed, as discussed in the literature review from von Hippel in 1977; Miller, Gartner, and Wilson in 1988; Day in 1994; McGrath in 1995; Zahra and George in 1999; Thornhill and Amit in 2001; to Miles and Covin in 2002, we see the criteria used to define the ICV varied (Cooper, Edgett, and Kleinschmidt 2001), and that there was considerable overlap of related phenomena (Table 2). Consequently, equivocal results emerge from the studies. In this study, data were collected in a manner to address this and other research design limitations in earlier studies.

\section{Data Collection}

Factiva was used to create a list of 78 corporations across multiple industries, listed on the NASDAQ or NYSE, with at least 20,000 employees, and over $\$ 1$ billion in sales. The purpose was to identify companies with a history of internal venturing and to obtain a variety of different internal venturing experiences. There were no intentional boundary conditions (i.e., limitations placed on the assumed applicability of our hypotheses). This is not an industry-specific theory, but a theory for ICV performance across industries and businesses. Some companies required that neither the company nor the respondents be explicitly identified. Nevertheless, the data set includes a fairly diverse set of industries and businesses-automotive, oil and gas, chemical, consumer products-and represents companies such as $3 \mathrm{M}$, Whirlpool, and P\&G. Geographically, the data set includes several U.S. states: Illinois, Indiana, Ohio, Kentucky, Michigan, Wisconsin, Minnesota, California, Georgia, Virginia, and Missouri, for a total of 38 ICVs. Data regarding ventures that did not meet the strict ICV definition and criteria were rejected, resulting in a smaller but more representative sample.

The corporations were then contacted and screened for a history of pursuing new business investments given that corporations are typically consistent in their investment types (Amit, Livnat, and Zarowin 1989). Fourteen of the corporations either directly stated that they did not pursue new ICVs, or it was determined that they did not, as defined in this study. Of the 64 remaining, a total of 16 participated (25 percent response rate), which exceeds the response rate for some new venture studies (McDougall and Robinson 1990).

To focus clearly on ICVs, respondents from the participating companies were asked to identify ventures that originated internally; were considered distinct from the company's existing products or services; and were intended as or became new businesses. This built upon the criteria used in previous studies (see Table 1) to eliminate or minimize contamination from related phenomena. Without a clear and explicit definition, researchers risk obtaining large samples that are not representative of the phenomena, since executives can define their business development activities in terms of corporate venture capital, acquisitions, joint ventures, and strategic alliances, as well as product development and extensions. Ventures were also 
limited to an age of no more than seven years, which is within the range of ages accepted for defining new ventures (Lussier 1995; McDougall 1989; Shrader, Oviatt, and McDougall 2000; Zahra 1996; Zahra, Ireland, and Hitt 2000).

A final important characteristic of the research design was that the data were collected using a two-part survey supplemented by interviews. The independent data were collected from the venture managers, who had the detailed knowledge regarding the operations of the venture, whereas the performance data were collected from the senior executives responsible for overseeing the business development activities and better able to report the parent's assessment of venture performance. Some of the various positions and titles of respondents are shown in Figure 1. Their respective questionnaires were completed independently, clearly separating the collection of dependent variable data from the independent variable data.

\section{Sample Size}

Without enough cases, one must either reduce the model or use techniques to compensate for size. When too few cases exist, results are difficult to find and can become highly sample specific (the extreme is called a "case study"). When too many cases exist, findings can actually be of little value as well. In fact, it is often forgotten that a sample size can be too large as well as too small, leading to type 1 and type II errors (i.e., rejecting the truth versus accepting a lie). In both situations, the issue is exacerbated if the sample is not representative of the phenomenon. The sample size needs to be large enough to detect important differences with high probability. In other words, we need to collect enough evidence to avoid condemning an innocent man by rejecting the presumption of innocence (Vogt 1999). However, if a sample size becomes too large, even unimportant dif-

\section{Figure 1 \\ Positions and/or Titles of Respondents}

Business development manager

Chief executive officer

Chief financial officer

Director

Director of new product integration

Executive vice president

Front-line leader

General manager

Group vice president

Innovation consultant

Marketing consultant

President

Product/project manager

Senior vice president of business development

Vice president

Vice president of business development

Vice president of marketing

Vice president of innovation

ferences (the untruths) can become statistically significant with high probability (this reflects the saying, if we hear a lie often enough, we might begin to think it true). The general assumption is that we need a ratio of 20 to 1 in terms of sample size to variables examined. Although this number is desirable, it is actually much higher than necessary for statistical analysis as noted by statisticians. 


\begin{tabular}{|c|c|c|c|c|c|c|c|c|}
\hline & Variable & Mean & S.D. ${ }^{a}$ & $\mathbf{1}$ & 2 & 3 & 4 & 5 \\
\hline 1 & $\begin{array}{l}\text { Internal Corporate } \\
\text { Venture } \\
\text { Performance }\end{array}$ & 4.378 & 1.64 & 1 & & & & \\
\hline 2 & Firm Size (log) & 4.807 & 0.31 & -0.114 & 1 & & & \\
\hline 3 & Venture Age & 4.546 & 2.94 & 0.011 & $0.432^{* * *}$ & 1 & & \\
\hline 4 & $\begin{array}{l}\text { Venture Structural } \\
\text { Autonomy }\end{array}$ & 3.575 & 1.91 & -0.131 & 0.143 & $0.291 *$ & 1 & \\
\hline 5 & $\begin{array}{l}\text { Venture Planning } \\
\text { Autonomy }\end{array}$ & 3.985 & 1.43 & $-0.398^{* * *}$ & 0.026 & -0.076 & -0.025 & 1 \\
\hline
\end{tabular}

${ }^{\text {a}}$ S.D., standard deviation.

*Significant at 0.10 level (two-tailed).

**:Significant at 0.05 level (two-tailed).

The general rule is that the ratio should never fall below 5 to 1 , meaning that there should be five observations for each independent variable in the variate. As this ratio falls below 5 to 1 , the researcher encounters the risk of "overfitting" the variate to the sample, making the results too specific to the sample and thus lacking generalizability (Hair et al. 1998, p. 166).

In his discussion of regression models, Long (1997, p. 54) also states, in "the literature on the covariance structure model, the rule of at least five observations per parameter is often given." Unfortunately, it seems that we will often sacrifice the quality of our sample in order to achieve a greater quantity of sample. Similarly, we ignore observable patterns in search of $p$-value confirmations. In this study, efforts have been made to improve upon both of these issues.

\section{Variables}

Face and content validity were checked by a group of researchers and executives. Confirmatory factor analysis was also conducted and showed proper loadings, with all loadings below the 0.600 threshold suppressed. The varimax rotation method was used, as is standard, with the rotation converging in 10 iterations. Overall, the research variables displayed good psychometric properties, which included strong Cronbach alphas of $0.78,0.89$, and 0.94 for VSA, VPA, and ICV performance, respectively. Table 3 provides the descriptive statistics and correlations.

Internal Corporate Venture (ICV) Performance. ICV performance was derived from a measure by Thornhill and Amit (2001), and measured based on agreement with the following statements rated on a seven-point Likert scale ( $1=$ strongly disagree to $7=$ strongly agree):

(1) This venture generally meets (or met) the expectations of the parent corporation.

(2) The parent corporation views (or viewed) this venture as being successful overall. 
(3) The parent corporation believes (or believed) that this venture achieved all of its milestones (i.e., events crucial to the venture's successful development) on schedule for each stage of its development.

(4) This venture is performing (or performed) well in terms of the criteria (e.g., market share, returns, satisfaction, learning, or positioning) that the parent corporation considers (or considered) most important to the venture's success.

Venture Structural Autonomy. VSA represented the extent to which the venture's operations were linked to those of other businesses of the corporation and was measured based on agreement with the following statements rated on a seven-point Likert scale ( $1=$ strongly disagree to $7=$ strongly agree):

(1) The venture operates as a selfcontained business unit, with few or weak structural or process linkages with other businesses of the corporation.

(2) The venture's operations are not significantly constrained or dictated by formal structural or process linkages with other businesses of the corporation.

(3) The venture operates in an independent manner vis-à-vis other businesses of the corporation.

Venture Planning Autonomy. VPA represented the extent to which the venture's management team was responsible for establishing goals, timetables, and strategy for the venture. The question stem for VPA was: "Who is responsible for each of the following planning and/or control related activities?" Planning autonomy for the venture was then measured based on the response to the five items below using a scale ranging from 1 to 7 , where $1=$ the sole responsibility of a higher level(s) (e.g., CEO and
Corporate) of authority within the corporation; $4=$ equal responsibility of venture-level and a higher level(s) of authority within the corporation; and, $7=$ the sole responsibility of venturelevel management:

(1) Setting the venture's goals.

(2) Establishment of a timetable (if applicable) for the achievement of the venture's goals.

(3) Choice of formal criteria used to measure the venture's performance.

(4) Formation or formulation of the venture's business strategy.

(5) Decision to change (if necessary) the venture's business strategy.

Controls. Three stages of venture development were used (Thornhill and Amit 2001): Early stage (defined as the year of first financial investment in the venture), middle stage (defined as the year the venture began to generate revenue), and established stage (defined as the year the venture became profitable). Whereas some ventures remain at a particular stage for an extended period, other ventures become established rather quickly. Therefore, controls were provided for the potential effects of venture age, defined as the length of time the venture has been established, the time since termination, or the time since first financial investment, accordingly. Parent size was measured by using the number of employees, as has been done in recent studies to avoid potential complications with revenues (Lee, Lee, and Pennings 2001; McGrath 2001).

As a test of robustness, a new hybrid control variable was created using a technique that increases the power of small samples. The new hybrid control was created based on the original controls (e.g., firm size, venture age, and venture stage), which were then regressed on each independent variable, and the standardized coefficients used to compute the hybrid control. Thus, if testing five 
Figure 2

\section{Graphical Analysis of Overall Relationship between Venture Planning Autonomy and Performance}

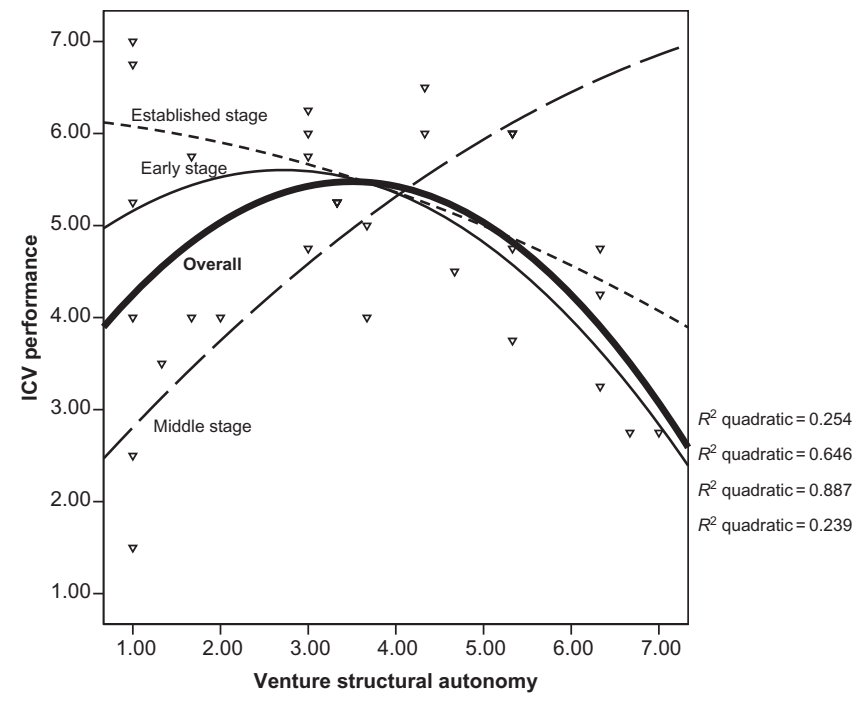

variables, then new controls would have to be computed (one for each variable). The hybrid control for variable number one would be: $\mathrm{IV}_{1}=\beta^{1} \times \mathrm{CV}_{1}+\beta^{2} \times$ $\mathrm{CV}_{2}+\beta^{3} \times \mathrm{CV}_{3}+\ldots \beta^{n} \times \mathrm{CV}_{n}$ containing all the respective variance, which then allows one hybrid control to be entered in place of five original controls. A new regression is then run using the hybrid control variable.

\section{Analysis and Results Autonomy and Performance}

Despite having a sufficient sample size (see Research Design), to corroborate any effects that might be questioned, the new hybrid control variable was created (see Variables: Controls). Various analyses were then rerun using the hybrid control variable. This approach can reduce $R^{2}$ values and result in fewer fitting models, but, in return, provides a robustness check.
The analyses began with a graphical examination of the hypothesized relationships between autonomy and performance. Graphical analysis is among the oldest and most versatile of analytical techniques, and has long been used and accepted in a variety of research (Bernstein and Cowden 1937; Chan, Makino, and Isobe 2006; Ruamsook, Russell, and Thomchick 2007). The Journal of Computational and Graphical Statistics published by the American Statistical Association (an established authority in statistical techniques) is devoted to extending the use of this often-misunderstood technique in statistics. The initial graphical analyses displayed a negative relationship between VPA and ICV performance (Figure 2) in support of $\mathrm{H} 1 \mathrm{~b}$, but a curvilinear (or inverted-U) relationship between VSA and ICV performance in support of $\mathrm{H} 3$ (Figure 3). 
Figure 3

\section{Graphical Analysis of Curvilinear Relationship between \\ Venture Structural Autonomy and Performance and Stage of Development (Early, Middle, and Established) Trend Effects}

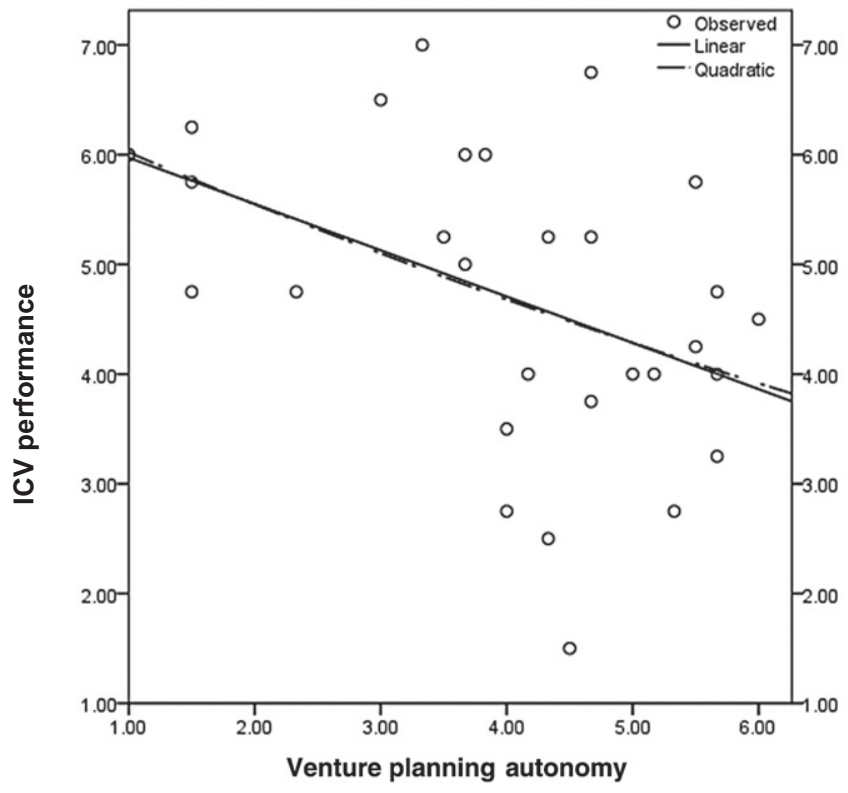

Using the regression curve estimation analysis of IBM SPSS Statistics package 19, VSA, as displayed in Figure 3, has a $R^{2}$ quadratic of 0.239 , VSA beta coefficient of 1.998 (significance $=0.015$ ), and a VSAsquared beta coefficient of -2.166 (significance $=0.009)$, indicating the strong curvilinear relationship. In comparison, VPA, as displayed in Figure 2, does not display a significant curvilinear relationship (VPA beta significance $=0.516$, and VPA-squared beta significance $=0.907$ ). However, for VPA, we do see a significant linear relationship $\left(R^{2}\right.$ linear $=0.210$, VPA beta coefficient $=-0.459$, significance $=$ 0.015). For further analysis, the VSA variable was squared within a standard regression model, showing that the second order effects indeed reached significance (beta $=-2.294, p<.05$ ). This relationship was also tested using the hybrid control and held (beta $=-2.122$, $p<.05$ ) (Table 4: models 1 and 2). Thus, the results of graphical analytical techniques are consistent with standard methods, with the added benefit of instant visual information, confirmation, and interpretation.

Main Effects and Interactions. Using linear regression in SPSS, controls were first entered, followed by VSA and VPA, and multiplicative interaction variables. Given the findings from the graphical analysis, the task was to examine each venture stage independently. Therefore, venture stage was used as a selection variable, which is a direct method to analyze stages that can provide a more fine-grained analysis similar to some more common approaches, such as moderated regression. 


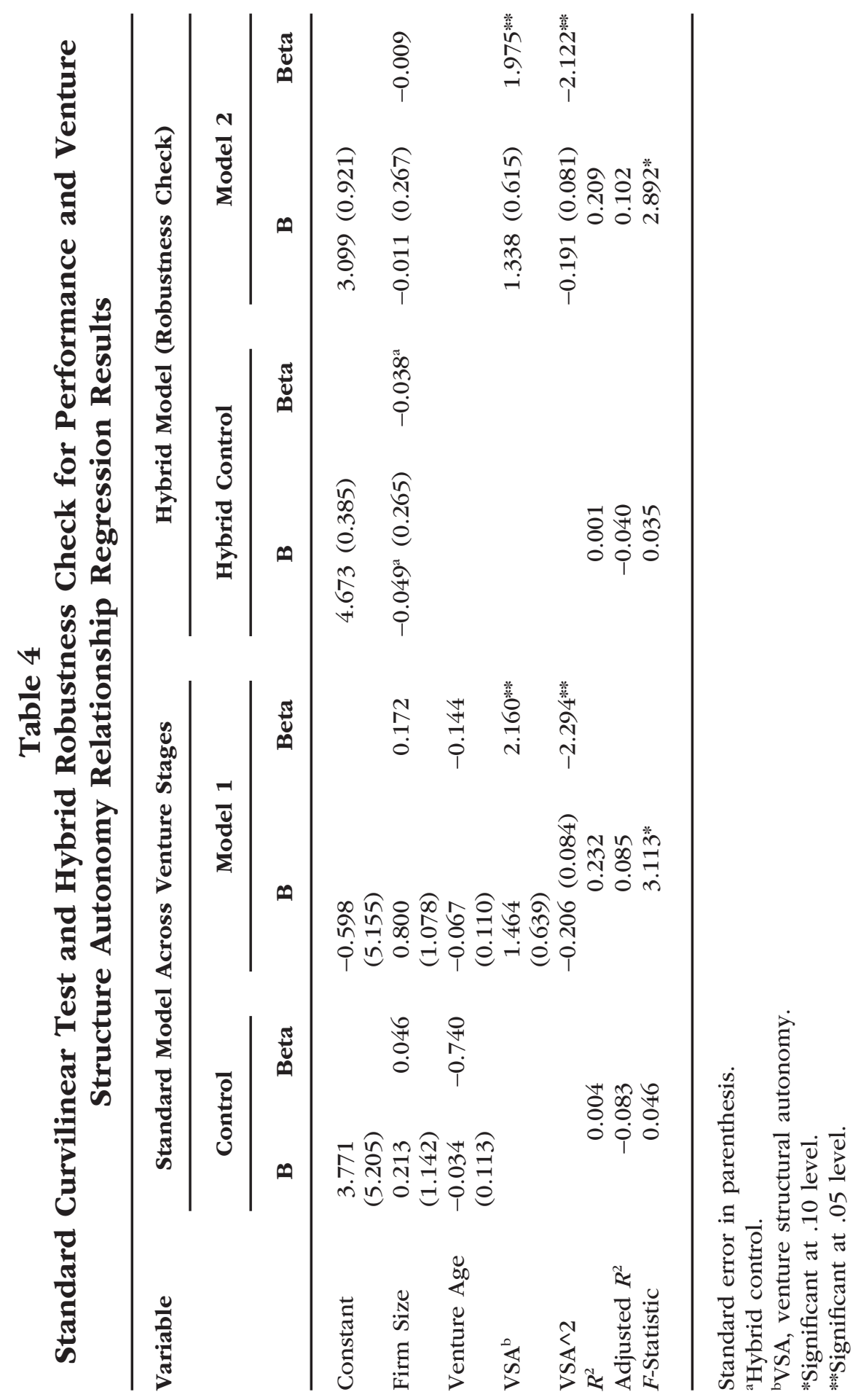


The first regression analysis was conducted across all venture development stages as with earlier research. Consistent with the graphical analytical technique, VPA was negative and significant providing strong support for H1b (beta = $-0.606, p<.01$ ) (Table 5, model 3). VSA, venture age, and firm size were not significant. There was no interaction effect.

Next examined were ventures that had progressed beyond the early stage. The nature of expectations might be less stringent during the early development stage versus later stages, thereby influencing performance perceptions. VPA remained negative and displayed a slightly greater effect size in later venture development stages (beta $=-0.685, p<.01$ ) (Table 5, model 4). VSA and size remained not significant, whereas venture age reached significance $(p<.10)$.

Given the consistency of the VPA results, the effect of VSA was partialed out, and another look taken of VPA across development stages. VPA remained significant (beta $=-0.615, p<.01$ ). Additionally, during later stages the effect size of VPA (beta $=-0.685, p<.01$ ) and age both increased. With the hybrid control, the previous results continued to hold (VPA: beta $=-0.549, p<.01$; VSA: not significant). The significant model accounted for 20.6 percent of the variance (Table 5, model 5), adding to the strong support for VPA, H1b. Likewise, the lack of a direct effect from VSA provides support for the basic premise that there are different types of autonomy, and that the nature of the relationship between autonomy and ICV performance is a function of the type of autonomy.

In summary, H1b (VPA is negatively associated with venture performance) was supported, and $\mathrm{H} 3$ (the stage of development of a venture moderates the relationship between performance and autonomy) was supported. $\mathrm{H} 2$ regarding VSA was not supported. However, it was discovered that there is a relationship between VSA and ICV performance to consider within specific venture development stages. For instance, a positive association between VSA and venture performance (similar to $\mathrm{H} 2 \mathrm{a}$ ) occurs with ventures in the middle stage of development, whereas a negative association with venture performance (similar to H2b) occurs with ventures when they reach the established stage. The early stage displays an inverted-U relationship.

\section{Discussion}

Every year, numerous companies, like Kraft, Disney, 3M, as well as smaller, lesser known companies, seek to develop new businesses known as ICVs within their established businesses. Among the myriad of decisions that have to be made for the successful development of the ICV is the decision regarding autonomy. Among many scholars, it is believed that the lack of autonomy for the venture leads to venture failure (Birkinshaw, Batenburg, and Murray 2002; Block and MacMillan 1993; Ginsberg and Hay 1994; MacMillan, Block, and Subbanarasimha 1986; Miller and Camp 1985; Sykes and Block 1989). Indeed, many of these early studies represent groundbreaking work that has been instrumental in our initial understanding of corporate venturing. Yet early empirical studies reflect equivocal results, and ICV performance continues to be random at best.

This study seeks to advance the research by empirically examining some popular assumptions using a more representative sample of the phenomenon. This paper focuses on different types or dimensions of autonomy that historically has been assumed to be a broad onedimensional construct that positively impacts ICV performance. However, two types of autonomy are distilled from the extant literature. Measures were subsequently developed, tested, and found to properly load on the two proposed types (or dimensions) of autonomy: VPA and VSA. These two types of venture 


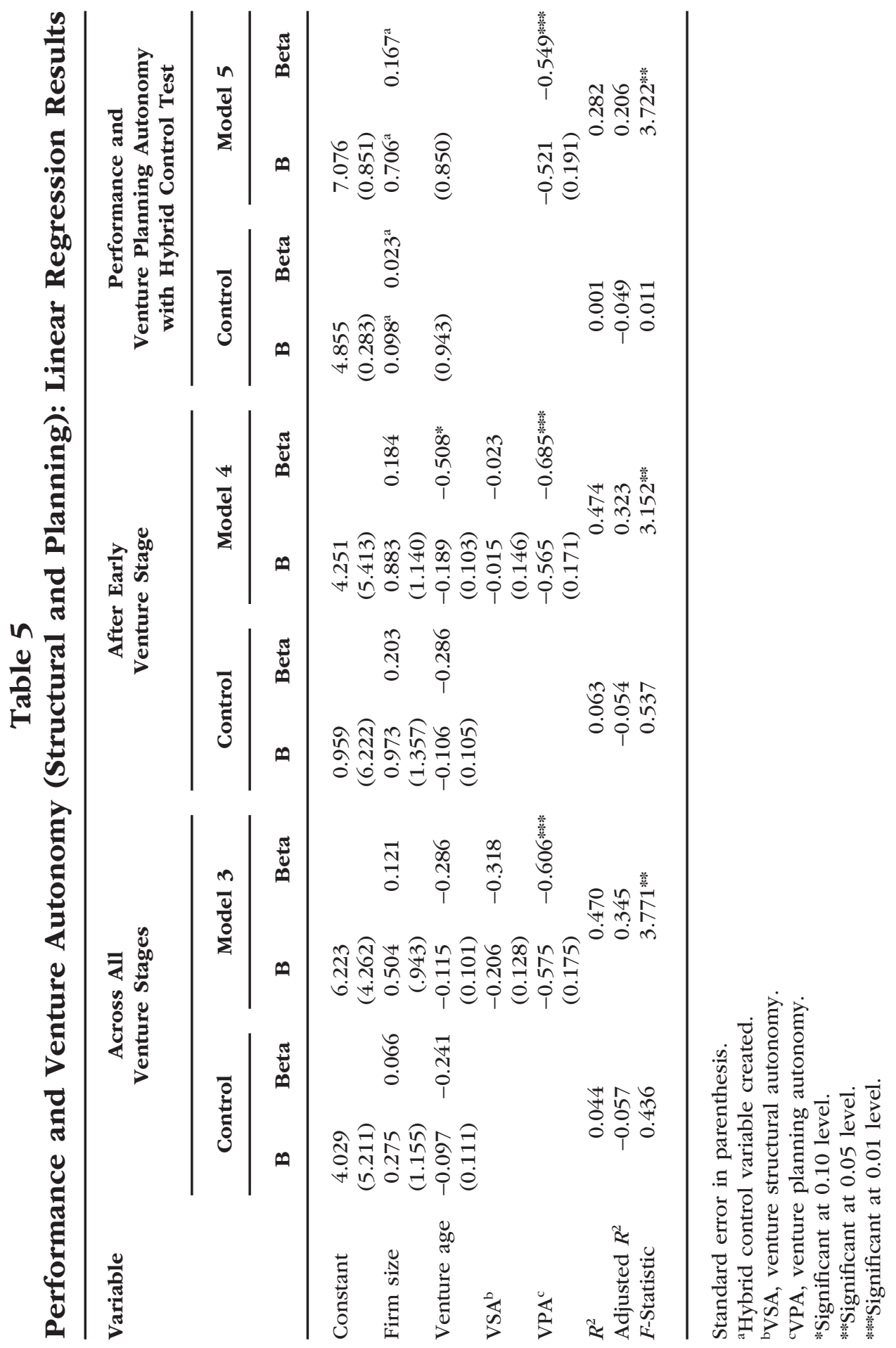


autonomy and the impact of venture stages are then analyzed in terms of their relationship with ICV performance given a sample of ICVs without related phenomena. The results are a new understanding of the autonomy-ICV performance relationship.

\section{VPA Findings}

The differences between what the parent wants and what the venture can deliver creates conflicts that are believed to adversely impact performance leading to conclusions for a "hands off" approach or, in other words, more VPA. Thus, popular belief is that an ICV is like an independent start-up and succeeds when separated from the parent organization and the venture managers are able to exercise independent decision-making (Birkinshaw, Batenburg, and Murray 2002; MacMillan, Block, and Subbanarasimha 1986; Sykes and Block 1989).

However, contrary to the popular belief to provide more VPA, this study finds that VPA is negatively associated with ICV performance. Rather than allowing venture managers to define the rules (Ginsberg and Hay 1994), this study finds that venture managers should embrace the venture-parent relationship and capitalize on the needs and benefits of that relationship. Ultimately, the venture exists for the parent organization, and thus we need to align the goals the parent has for the venture with the actual capabilities of the venture, resulting in more realistic expectations. Proper and clear goal alignment will also reduce conflicts. This alignment is critical given that ICVs are really inventions of established businesses (i.e., a parent organization), and what the parent wants is what it must deliver. These internal ventures might better be called "inventures" since, like "inventions," if they do not show promise, they might be scrapped or placed upon a shelf and virtually forgotten.

In summary, although both arguments for and against VPA are plausible, our analysis of a more representative sample indicates that less VPA is associated with the more successful ventures. The effect is strong, significant, and explains from 20 to 34 percent of the performance variance (Table 5). Therefore, when it comes to the strategies, operations, and planning, the data show that the more involved the parent the better the performance of the ICV in terms (such as market share, returns, satisfaction, learning, or positioning), which are important to the parent. Of course, we ask why these findings are contrary to popular belief. The anecdotal evidence of the belief of more autonomy neglects the type of autonomy, as well as the venture's stage of development.

\section{VSA Findings}

The second form of venture autonomy-VSA-considers the links between the venture and existing parental business units. For a new ICV in the purest sense, there would be no linkages, and the venture would be virtually independent. As revealed through the separate interviews, this is an extremely rare situation, since in the pursuit of a new business there always tends to be some connection with an existing business. Nevertheless, contrary to expectations, there was no significant linear relationship between VSA and ICV performance, thereby pouring even more doubt on the popular belief for more autonomy.

Venture Stage Moderator. VPA is not impacted by the venture's stage of development, but VSA depends upon it. Although the stages of development for an ICV are distinct, research supports the importance of stages of development or life cycles for organizations (Drazin and Kazanjian 1990; Kazanjian and Drazin 1989, 1990). Similarly, we find that the nature of the relationship between VSA and ICV performance changes as the venture develops. A positive association (similar to $\mathrm{H} 2 \mathrm{~A}$ ) occurs with ventures in 
the middle stage of their development, whereas a negative association occurs (similar to H2B) with ventures that have reached the established stage. Interestingly, during the early stage-perhaps the most critical for a start-up as wellthe relationship displays a more complex inverted-U shape. This reflects the delicate balance between the venture and parent in the initial positioning of the venture, and, although unexpected, it is intuitively appealing given that VSA represents the operational linkages for a dynamic ICV. The changing nature of the relationship between VSA and performance may also account for some of the popular beliefs and inconsistent results when autonomy is treated as a broad construct.

For instance, when a new venture is initially pursued, we are aware of the conflicts that can arise between venture and other business units (Tidd and Taurins 1999), which may lead us to seek to separate them, but research has also shown that separation can breed conflict (Birkinshaw, Batenburg, and Murray 2002; Garvin 2002, 2004; Sobkowiak 2002). This tension may be in part due to the venture needing to be both different and familiar at the same time, and needing to be both free of the policies imposed upon existing units (Thornberry 2003) while still conforming to the established protocols for all units by virtual of being a part of the parent organization. Thus, without structural autonomy, the venture is more likely to fail, and with too much structural autonomy, the venture is still likely to fail. Optimization becomes the key.

During the middle stage when managers are perhaps excited about the new venture's growth, the venture's performance benefits from autonomy. However, as we can see in the graph, the benefit of additional VSA begins leveling off and completely reverses upon the venture reaching the established stage (see Figure 3). Some of the findings of this study are supported by a recent case study that suggested that ventures should be managed in stages with stagespecific reviews, and that new markets require learning by the organization and changes in direction (McGrath, Keil, and Tukiainen 2006). Without an understanding of this dynamic, a venture might simply by chance quickly complete the early stage (recall venture age reached significance after the early venture development stage, indicating a potential benefit to younger ventures later) and benefit from the increasing level of autonomy being provided to it because managers were observing performance improvements unaware of the changing relationship. Unfortunately, the ICV will then encounter an unanticipated obstacle from the high level of autonomy; and, if not corrected, fail to become established. It will be terminated or abandoned.

\section{Autonomy Types and Stages in Action}

Given that the findings of this study are contrary to popular belief, it leads to a question of how can we reconcile these results? The differences are likely the result of premises of the study as reflected in three issues: (1) having an uncontaminated sample, (2) distinguishing the different types of autonomy, and (3) considering the stage of the venture. Similarly, "Is there evidence in practice of what these findings show?" Of course, evidence opposing popular belief is often not apparent-otherwise it would probably not be "popular." Nevertheless, the need for VPA to reside at the corporate-level (i.e., low VPA), and the dependence of VSA (e.g., operational protocols) on the venture stage is reflected in some recent history and events.

For example, given its domination of the animation industry, the Walt Disney Company became complacent in its success. Unfortunately, rather than continue to internally innovate into new 
characters, Disney invested resources into retaining the Mickey Mouse character copyright. Disney won the copyright extension (known as the Digital Millennium Copyright Act), but lost its competitive advantage in creativity and animation. This led Disney to partner with a largely unknown, but upcoming company known as Pixar, and, eventually Disney even acquired Pixar Studios once the alliance contract ended.

Despite the Pixar acquisition, without any other strategy, Disney's downward spiral would definitely continue if the Pixar competencies were lost in the acquisition. However, rather than engage in the typical postacquisition integration, Disney CEO Bob Iger prudently kept Pixar intact and gave control of Disney's animation operations to the former Pixar executives, Catmull and Lasseter. A co-director at Disney, Mr. Musker, stated, "It's unusual for Hollywood, making the key creative people sort of in charge of the actual decisions and less the studio executives, to some degree" (emphasis added) (Sanders 2008, B1). Mr. Musker is alluding to VPA, and, per his statement, it was not the norm.

In addition to VPA not being the norm at Disney, it still is not. Disney executives set Pixar within its portfolio and promoted the Pixar executives into Disney executives, and gave them control over Disney's animation operations. Thus, contrary to the impression that the venture managers were now in charge of decisions, Disney executives were overseeing the many animation ideas being pursued (in other words, the ICVs!). Recall that the corporate-level managers are those responsible for overseeing the many business development activities. The equivalent of venture-level manager is the writer and/or director. Mr. Lasseter, the new "executive" in charge of Disney's animation operations, replaced the writer and director of an original script (an ICV equivalent) with two new directors (venture-level managers) based on creative differences (Sanders 2008, B1). These actions by Disney reflect an understanding of the nature of venture autonomy and performance consistent with this study and contrary to popular assumptions.

\section{Limitations}

Steps taken to improve upon the trade-offs of previous studies have an unfortunate trade-off as well-they reduce the sample size. Additionally, many corporations tend to be reluctant to disclose their ICV data partly due to the competitive nature of the information; partly due to inconsistencies regarding what constitutes an ICV, and partly due to their abysmal success rates (executives tend to disassociate themselves with failures). There are also no publicly available ICV databases containing the needed information for research purposes. The overall effect of these conditions is a smaller sample than desired. Although the sample size is still sufficient (Hair et al. 1998; Long 1997; Vogt 1999) and the sample itself improves upon previous studies, the size presents a serious threat to the research by reducing the power of the study to find significance. However, despite the sample size, significant findings were made. Of course, significant findings based on a small sample size are very compelling and support the need for further research utilizing larger samples.

There are also biases and conflicts of interest to consider. VPA measures the extent to which the venture's management team was responsible for establishing the goals, timetables, and strategy for the venture. Among some of the items are setting the goals and performance measurement for the venture. However, a venture manager may not consider the performance of a venture independent of his own performance. Therefore, it is possible that when venture managers evaluate ICV performance that their self- 
assessment could be more biased, whereas the upper-level executives might not be as impressed with the achievements of the venture and reflect no personal bias or connection in their assessment. This negative correlation could potentially be an artifact of low VPA. Based on the data, we believe it points out the importance of the higherlevel management involvement in the criteria for the performance evaluation. We also believe this is an important consideration since the evaluation of the venture at each stage of development and whether it continues to receive support is ultimately determined by the upper-level executives. During this study, performance information was collected from both the executive in charge as well as the venture manager. However, the executive in charge was used in the analyses for previously stated reasons.

Finally, there is the issue of survival. Indeed, as discovered in the supplemental interviews, an ICV can become orphaned. Other ICVs are metaphorically kept on life support because no one wants to "pull the plug." Thus, despite the best efforts, there are notable limitations to every study. Although steps were taken to move in the direction of causality, the associations discovered in this study are not intended to describe causal relationships but to identify potentially key variables associated with the phenomenon. Lastly, this is not intended to be an exhaustive list of limitations but to remind the reader that all research has trade-offs that we should consider with any conclusions or subsequent recommendations to management.

\section{Implications for Management}

Executives responsible for maintaining and growing existing businesses often look for a "balance between stability and innovation" (Klavans, Shanley, and Evan 1985, p. 26). Of the growth avenues available (Garvin 2002, 2004), the development of a new business is perhaps among the most rewarding and challenging. Popular belief is that if you can run an established business, then you can start a new business. However, we know that the skills needed are not always the same. Additionally, implicit beliefs appear to collide with business realities. Prior studies suggest that managers should cocoon new ventures, or treat them as isolated islands, or take other steps to shield and protect the fledgling venture (Garvin 2002; Ginsberg and Hay 1994). However, new data suggest that the prevailing suggestion to give greater autonomy to venture managers would not only undermine the venture-parent relationship, but adversely impact ICV performance. Findings from this study show a strong negative association between VPA and performance. The findings reveal to managers that the goals, timetables, strategy, performance measures, and overall planning for the venture should be diligently controlled by the parent so as to not undermine future development nor create conflict (i.e., sibling rivalry). Furthermore, the degree of operational links and protocol constraints should take into account the actual developmental stage of the venture to determine the appropriate role of autonomy. Of course, high corporate-level involvement with the venture does not necessarily mean that the venture should be subjected to the same policies and protocol for other business units. High corporate-level involvement simply recognizes that the ICV needs the thoughtful tutelage of the parent though an active planning role. The actual structure of the venture, however, is a separate issue driven by the stage of development of the venture.

In the early stages of venture development, managers search for the balance between control and freedom. Data suggest that managers should put more focus initially on understanding the 
business distinctions and communicating why the venture is of strategic interest. This must be accomplished without neglecting to acknowledge its link to the existing businesses or markets. This link provides familiarity and comfort regarding the venture as it develops, and, as the venture moves into the middle stage of development, managers need to maximize structural autonomy, which will have to be reversed as the venture becomes established.

In summary, success depends upon understanding the types of autonomy and the dynamic nature of the autonomyperformance relationship. Autonomy should be actively monitored and tuned. VPA should be minimized and controlled by corporate executives regardless of venture stage. However, the development stage of the venture must be taken into account when determining the appropriate VSA. In the early stage, a careful balance of freedom and control must be achieved. During the middle stage, management should shift focus to the distinctive value of the ICV and allow it to operate more independently. In the final stage, the venture should become a recognized addition to the existing group of businesses operating under the established protocols. Lastly, as the developmental time becomes prolonged and a venture becomes older, many ventures experience diminishing performance, and, if not shut down, can become orphaned. Therefore, corporate- and venture-level managers need to be proactive to keep the venture moving forward and prohibit lingering.

\section{Future Research}

Given the findings of this study, the acquisition of larger samples could provide a deeper examination of the discovered effects of autonomy and venture stage, and provide greater generalizability. Keeping in mind the importance of a representative sample, researchers might examine the popular belief that similari- ties between a venture and parent, specifically in terms of their products and technologies, supports ICV performance; or, from a resource-based perspective, researchers might examine whether the type of resources also impact ICV performance when we take into consideration the role of autonomy in those relationships.

This study found two dimensions to venture autonomy, but we can consider not only their impact on ICV pursuits, but other business development activities. For scholars, the development and discovery of two new measures of autonomy that are significant in ICV performance opens up new research possibilities into our understanding of internal ventures and other organizations. Furthermore, a case study focused on the experiences of a single company could provide insights into the relationship between autonomy in terms of implementation strategies or specific types of ICVs.

Future research should examine the need for organizations to differentiate structures in the parent-venture relationship. A particularly interesting study would take the curvilinear nature of VSA and examine how organizations adapt structures that best conform to performance expectations. Indeed, given that during the initial stage of development the venture is adversely impacted by both too much and too little structural autonomy, we want to understand the optimal level of VSA and the driving factors. Similarly, future research should examine when an ICV is more likely to be abandoned versus terminated. Understanding the drivers of these outcomes could contribute to our understanding of how to avoid them. Lastly, we might examine the knowledge transfer that takes place within organizations engaged in corporate entrepreneurship activities with a specific focus on ICVs.

Finally, autonomy is not the only variable that has been assumed to influence performance outcomes. Additional 
studies are needed to find and examine other factors. Ultimately, being able to address the question of a successful ICV design strategy for companies is where I envision this line of research taking us.

\section{Conclusions}

In my effort to address several research design problems found in earlier studies and to highlight differences between them, and by implication, the contribution of this work, the tendency is to become overly critical. However, the contribution of prior scholars, which in fact inspired this study, is fully recognized and acknowledged. Any discoveries herein are in part a continuation of those early efforts, and, hopefully, in some small part, help advance our understanding of corporate venturing.

Representative samples are always sought, but determining what is representative and obtaining such a sample is both challenging and imperative. Therefore, when related phenomena have been used and the resulting findings continuously reflect equivocal results, then we need to reexamine our research designs. Consequently, the sample criteria was derived from a review of the literature and designed to eliminate contamination from related phenomena. Quantity was desired, but quality was preferred; therefore, data were discarded if determined to be of a related phenomenon. This step was taken with the expectation that if the sample is representative of the truth, then the overall relationship is more likely to be revealed in the analysis.

By also discerning some of the nuances of the phenomenon in the extant literature, two forms of autonomy were theorized: planning and structural. By developing and examining these two types of venture autonomy, it was (1) shown that there are indeed different types, (2) shown that the type of venture autonomy is independently important to performance; and (3) discovered that the nature of some autonomy-performance relationships is influenced by the venture's stage of development. Further improvements were achieved by collecting the independent variables from the venture managers and the dependent variable separately from senior executives.

Consequently, the findings of this research are important to companies seeking innovative growth and development. The basic research question examined is: Do ICVs designed with more autonomy perform better than those designed with less autonomy? I believe we can now offer a preliminary answer to this question based on the type of autonomy and the venture's stage of development. From the empirical analysis of this primary data, we see that despite the desire for greater autonomy to establish the goals, timetables, or strategy by those who directly manage ICVs, an ICV is better served with less autonomy. In contrast, the complexity of structural autonomy requires management to be cognizant of the development stage of the venture when determining the appropriate level of autonomy. There is an inverted-U relationship in the early stage; a positive relationship in the middle stage; and a negative relationship at the established stage. This has never before been empirically known, shown, or expected. Overall, the ICV has proven to be an intriguing phenomenon within corporate entrepreneurship, and, given its value to organizational growth and innovation, it remains a viable and important area for research.

\section{References}

Amit, R., J. Livnat, and P. Zarowin (1989). "The Mode of Corporate Diversification: Internal Ventures versus Acquisitions," Managerial and Decision Economics 10, 89-100.

Antoncic, B., and I. Prodan (2008). "Alliances, Corporate Technological Entrepreneurship and Firm Performance: Testing a Model on 
Manufacturing Firms," Technovation 28(5), 257-265.

Baysinger, B. D., and R. E. Hoskisson (1989). "Diversification Strategy and R\&D Intensity in Large Multiproduct Firms," Academy of Management Journal 32(2), 310-332.

Bernstein, E. M., and D. J. Cowden (1937). "Graphic Presentation of Trend Data," Southern Economic Journal 3(4), 700-709.

Biggadike, R. (1976). "Entry, Strategy, and Performance," Boston, MA: Doctoral Dissertation, Harvard Business School.

- (1979). "The Risky Business of Diversification," Harvard Business Review 57(3), 103-111.

Birkinshaw, J. (2005). "The Secret Diary of Corporate Venturing," Business Strategy Review 16(2), 19-24.

Birkinshaw, J., R. Batenburg, and G. Murray (2002). "Venturing to Succeed," Business Strategy Review 13(4), 10-17.

Block, Z. (1982). "Can Corporate Venturing Succeed?," The Journal of Business Strategy 3(2), 21-33.

_ (1989). "Damage Control for New Corporate Ventures," The Journal of Business Strategy 10(2), 22-28.

Block, Z., and I. C. MacMillan (1993). Corporate Venturing: Creating New Businesses within the Firm. Boston: Harvard Business School Press.

Boeker, W., and R. Karichalil (2002). "Entrepreneurial Transitions: Factors Influencing Founder Departure," The Academy of Management Journal 45(4), 818-826.

Brown, S. L., and K. M. Eisenhardt (1995). "Product Development: Past Research, Present Findings, and Future Directions," Academy of Management Review 20(2), 343-378.

Burgelman, R. A. (1983). "A Process Model of Internal Corporate Venturing in the Diversified Major Firm," Administrative Science Quarterly 28, 223244. (1984a). "Designs for Corporate Entrepreneurship in Established Firms," California Management Review 26(3), 154-166.

(1984b). "Managing the Internal Corporate Venturing Process," Sloan Management Review 25(2), 33-48.

- (1984c). On the Interplay of Process and Content in Internal Corporate Ventures: Action and Cognition in Strategy-Making.

Campbell, A., and R. Park (2004). "Stop Kissing Frogs," Harvard Business Review 82(7/8), 27-28.

Campbell, A., J. Birkinshaw, A. Morrison, and R. Van Basten Batenburg (2003). "The Future of Corporate Venturing," Sloan Management Review 45(1), 30-37.

Campbell, D. T., and D. W. Fiske (1959). "Convergent and Discriminant Validation by the Mutitrait-Multimethod Matrix," Psychological Bulletin 56, 81-105.

Chan, C. M., S. Makino, and T. Isobe (2006). "Interdependent Behavior in Foreign Direct Investment: The Multilevel Effects of Prior Entry and Prior Exit on Foreign Market Entry," Journal of International Business Studies 37(5), 642-665.

Chandler, G. N., and S. H. Hanks (1994). "Market Attractiveness, ResourceBased Capabilities, Venture Strategies, and Venture Performance," Journal of Business Venturing 9, 331-349.

Chesbrough, H. W. (2000). "Designing Corporate Ventures in the Shadow of Private Venture Capital," California Management Review 42(3), 31-49.

Chrisman, J. J., A. Bauerschmidt, and C. W. Hofer (1998). "The Determinants of New Venture Performance: An Extended Model," Entrepreneurship Theory and Practice 22(1), 5-29.

Cooper, R., S. Edgett, and E. Kleinschmidt (2001). "Portfolio Management for New Product Development: Results of an Industry Practices Study," RED Management 31(4), 361-380. 
Covin, J. G., and M. P. Miles (2007). "Strategic Use of Corporate Venturing," Entrepreneurship Theory and Practice 31(2), 183-207.

Crawford, C. M. (1994). New Products Management. Burr Ridge, IL: Richard D. Irwin, Inc.

Day, D. L. (1994). "Raising Radicals: Different Processes for Championing Innovative Corporate Ventures," Organizational Science 5(2), 148-172.

Dougherty, D. (1995). "Managing Your Core Incompetencies for Corporate Venturing," Entrepreneurship Theory and Practice 19(3), 113-135.

Drazin, R., and R. K. Kazanjian (1990). "Research Notes and Communications: A Reanalysis of Miller and Friesen's Life Cycle Data," Strategic Management Journal 11, 319-325.

Ensley, M. D., A. W. Pearson, and A. C. Amason (2002). "Understanding the Dynamics of New Venture Top Management Teams: Cohesion, Conflict, and New Venture Performance," Journal of Business Venturing 17, 365-386.

Garvin, D. A. (2002). "A Note on Corporate Venturing and New Business Creation," Harvard Business School, 1-20.

(2004). "What Every CEO Should Know about Creating New Businesses," Harvard Business Review 82(7/8), 18-21.

George, R., and I. C. MacMillan (1985). "Corporate Venturing: Venture Management Challenges," The Journal of Business Strategy 6(2), 85-91.

Ginsberg, A., and M. Hay (1994). "Confronting the Challenges of Corporate Entrepreneurship," European Management Journal 12(4), 382-389.

Glaister, K. W., R. Husan, and P. J. Buckley (2003). "Decision-Making Autonomy in UK International Equity Joint Ventures," British Journal of Management 14(4), 305-322.

Gomes, J., P. D. Weerd-Nederhof, A. Pearson, and O. Fisscher (2001).
"Senior Management Support in the New Product Development Process," Creativity and Innovation Management 10(4), 234-242.

Gooding, R. Z., and J. A. W. Wagner III (1985). "A Meta-Analytic Review of the Relationship between Size and Performance: The Productivity and Efficiency of Organizations and Their Subunits," Administrative Science Quarterly 30, 462-481.

Greene, P. G., C. G. Brush, and M. M. Hart (1999). "The Corporate Venture Champion: A Resource-Based Approach to Role and Process," Entrepreneurship Theory and Practice 23(3), 103-122.

Hair, J. F., Jr, R. E. Anderson, R. L. Tatham, and W. C. Black (1998). Multivariate Data Analysis, 5th ed. Upper Saddle River, NJ: Prentice-Hall.

Henard, D. H., and D. M. Szymanski (2001). "Why Some New Products Are More Successful than Others," Journal of Marketing Research 38, 362-375.

Hobson, E. L., and R. M. Morrison (1983). "How Do Corporate Start-up Ventures Fare?," in Frontiers of Entrepreneurship Research. Ed. J. A. Honaday, J. A. Timmons, and K. H. Vesper. Wellesley, MA: Babson College Center for Entrepreneurial Studies.

Hornsby, J. S., D. F. Kuratko, and S. A. Zahra (2002). "Middle Managers' Perception of the Internal Environment for Corporate Entrepreneurship: Assessing a Measurement Scale," Journal of Business Venturing 17(3), 253-273.

Hoy, F. (2006). "The Complicating Factor of Life Cycles in Corporate Venturing," Entrepreneurship Theory and Practice 30(6), 831-836.

Karagozoglu, N. (1988). "Innovative Behavior of Firms in a Developing Country: An Empirical Study," Engineering Management International 5(2), 121-129.

Kazanjian, R. K., and R. Drazin (1989).

"An Empirical Test of a Stage of 
Growth Progression Model," Management Science 35(12), 1489-1503.

(1990). "A Stage-Contingent Model of Design and Growth for Technology Based New Ventures," Journal of Business Venturing 5(3), 137-150.

Klavans, R., M. Shanley, and W. M. Evan (1985). "The Management of Internal Corporate Ventures: Entrepreneurship and Innovation," Columbia Journal of World Business 20(2), 21-27.

Ledwith, A. (2000). "Management of New Product Development in Small Electronic Firms," Journal of European Industrial Training 24, Product Development and Innovation, 137-148.

Lee, C., K. Lee, and J. M. Pennings (2001). "Internal Capabilities, External Networks, and Performance: A Study of Technology-Based Ventures," Strategic Management Journal 22, 615-640.

Long, J. S. (1997). Regression Models for Categorical and Limited Dependent Variables (Vol. 7). Thousand Oaks, CA: Sage Publications, Inc.

Lumpkin, G. T., and G. G. Dess (1996). "Clarifying the Entrepreneurial Orientation Construct and Linking It to Performance," Academy of Management Review 21(1), 135-172.

Lumpkin, G. T., C. C. Cogliser, and D. R. Schneider (2009). "Understanding and Measuring Autonomy: An Entrepreneurial Orientation Perspective," Entrepreneurship Theory and Practice 33(1), 47-69.

Lussier, R. N. (1995). "A Nonfinancial Business Success versus Failure Prediction Model for Young Firms," Journal of Small Business Management 33(1), 8-20.

Luther, J. W. (1984). "How CEOs Can Help Improve the Odds for Market Success," Management Review 73(7), 18-24.

Lyon, D. W., G. T. Lumpkin, and G. G. Dess (2000). "Enhancing Entrepreneurial Orientation Research: Operationalizing and Measuring a Key Strategic Decision Making Process,"
Journal of Management 26(5), 10551085.

MacMillan, I. C., and D. L. Day (1987). "Corporate Ventures into Industrial Markets: Dynamics of Aggressive Entry," Journal of Business Venturing, Winter.

MacMillan, I. C., Z. Block, and P. N. Subbanarasimha (1986). "Corporate Venturing: Alternatives, Obstacles Encountered and Experience Effects," Journal of Business Venturing 1(2), 177-191.

Matthews, C. H., and S. E. Human (2004). "The Economic and Community Context for Entrepreneurship: Perceived Environmental Uncertainty," in Handbook of Entrepreneurial Dynamics: The Process of Business Creation. Eds. W. G. Gartner, K. G. Shaver, N. M. Carter and P. D. Reynolds. Thousand Oaks, CA: Sage, 94-103.

McCrea, E., and S. C. Betts (2008). "Failing to Learn from Failure: An Exploratory Study of Corporate Entrepreneurship Outcomes," Academy of Strategic Management Journal 7, 111132.

McDougall, P. P. (1989). "International Versus Domestic Entrepreneurship: New Venture Strategic Behavior and Industry Structure," Journal of Business Venturing 4, 387-399.

McDougall, P. P., and R. Robinson (1990). "New Venture Strategies: An Empirical Identification of Eight 'Archetypes' of Competitive Strategies for Entry," Strategic Management Journal 11, 447-467.

McGrath, R. G. (1995). "Advantage from Adversity: Learning from Disappointment in Internal Corporate Ventures," Journal of Business Venturing 10(3), 121-142.

- (2001). "Exploratory Learning, Innovative Capacity, and Managerial Oversight," Academy of Management Journal 44(1), 118-131.

McGrath, R. G., and I. C. MacMillan (2000). The Entrepreneurial Mindset. 
Boston, MA: Harvard Business School Press.

McGrath, R. G., T. Keil, and T. Tukiainen (2006). "Extracting Value from Corporate Venturing," MIT Sloan Management Review 48(1), 50-56.

Miles, M. P., and J. G. Covin (2002). "Exploring the Practice of Corporate Venturing: Some Common Forms and Their Organizational Implications," Entrepreneurship Theory and Practice 26(3), 21-40.

Miller, A., and B. Camp (1985). "Exploring Determinants of Success in Corporate Ventures," Journal of Business Venturing 1, 87-105.

Miller, A., W. B. Gartner, and R. Wilson (1988). "Entry Order and Its Relationship to Market Share and Competitive Advantage: A Study of New Corporate Ventures," Academy of Management Best Papers Proceedings 64-68.

Miller, A., M. S. Spann, and L. Lerner (1991). "Competitive Advantages in New Corporate Ventures: the Impact of Resource Sharing and Reporting Level," Journal of Business Venturing 6(5), 335-350.

Miller, D. (1983). "The Correlates of Entrepreneurship in Three Types of Firms," Management Science 29, 770791.

Miller, D., and P. Friesen (1982). "Innovation in Conservative and Entrepreneurial Firms: Two Models of Strategic Momentum," Strategic Management Journal 3(1), 1-25.

Paik, Y., and D. Y. Choi (2007). "Control, Autonomy and Collaboration in the Fast Food Industry," International Small Business Journal 25(5), 539562.

Palmer, A., and C. Cole (1995). Services Marketing: Principles and Practice. Englewood Cliffs, NJ: Prentice-Hall, Inc.

Rauch, A., J. Wiklund, G. T. Lumpkin, and M. Frese (2009). "Entrepreneurial Orientation and Business Perfor- mance: An Assessment of past Research and Suggestions for the Future," Entrepreneurship: Theory and Practice 33(3), 761-787.

Robins, J. A., S. Tallman, and K. Fladmoe-Lindquist (2002). "Autonomy and Dependence of International Cooperative Ventures: An Exploration of the Strategic Performance of U.S. Ventures in Mexico," Strategic Management Journal 23(10), 881-900.

Ruamsook, K., D. Russell, and E. Thomchick (2007). "U.S. Sourcing from Low-Cost Countries: A Comparative Analysis of Supplier Performance," Journal of Supply Chain Management 43(4), 16-30.

Sandberg, W. R. (1986). New Venture Performance: The Role of Strategy and Industry Structure. Lexington, MA: Lexington Books.

Sandberg, W. R., and C. W. Hofer (1987). "Improving New Venture Performance: the Role of Strategy, Industry Structure, and the Entrepreneur," Journal of Business Venturing 2, 5-28.

Sanders, P. (2008). "Disney Learns from Pixar: Storied Animation Studio's New 3-D Computer-Generated Film Showcases Melding of Pixar Talent," Wall Street Journal Marketplace, B1.

Sharma, P., and J. J. Chrisman (1999). "Toward a Reconciliation of the Definitional Issues in the Field of Corporate Entrepreneurship," Entrepreneurship Theory and Practice 23(3), 11-27.

Shrader, R. C., B. M. Oviatt, and P. P. McDougall (2000). "How New Ventures Exploit Trade-Offs among International Risk Factors: Lessons for the Accelerated Internationalization of the 21st Century," Academy of Management Journal 43(6), 1227-1247.

Siegel, R., E. Siegel, and I. C. Macmillan (1993). "Characteristics Distinguishing High-Growth Ventures," Journal of Business Venturing 8, 169-180.

Simon, M., and S. M. Houghton (2003). "The Relationship between Overconfidence and the Introduction of Risky 
Products," The Academy of Management Journal 46(2), 139-149.

Simon, M., and R. C. Shrader (1997). "Corporate versus Independent New Ventures: Resource, Strategy, and Performance Differences," Journal of Business Venturing 12(1), 47-66.

Sobkowiak, R. T. (2002). "Corporation Start-up Dynamics: How the Parent Corporation and the Start-up Have to Change," Human Resource Planning 25(3), 18-28.

Storey, C. D., and C. J. Easingwood (1996). "Determinants of New Product Performance: A Study in the Financial Services Sector," International Journal of Industry Management 7(1), 32-55.

Story, V., G. Smith, and J. Saker (2001). "Developing Appropriate Measures of New Product Development: A Contingency-Based Approach," International Journal of Innovation Management 5(1), 21-47.

Stuart, R., and P. A. Abetti (1987). "Start-up Ventures: Toward the Prediction of Initial Success," Journal of Business Venturing, Summer.

Sykes, H. B., and Z. Block (1989). "Corporate Venturing Obstacles: Sources and Solutions," Journal of Business Venturing 4(3), 159-167.

Thornberry, N. E. (2003). "Corporate Entrepreneurship: Teaching Managers to Be Entrepreneurs," The Journal of Management Development 22(4), 329344.

Thornhill, S., and R. Amit (2001). "A Dynamic Perspective of Internal Fit in Corporate Venturing," Journal of Business Venturing 16(1), 25-50.

Tidd, J., and S. Taurins (1999). "Learn or Leverage? Strategic Diversification and Organizational Learning Through Corporate Ventures," Creativity and Innovation Management 8(2), 122-129.

Tushman, M., and D. Nadler (1986). "Organizing for Innovation," California Management Review 28(3), 7492.
Vogt, W. P. (1999). Dictionary of Statistics \& Methodology: A Nontechnical Guide for the Social Sciences, 2nd ed. Thousand Oaks, CA: Sage Publications, Inc.

von Hippel, E. A. (1977). "Successful and Failing Internal Corporate Ventures: An Empirical Analysis," Industrial Marketing Management 6, 163-174.

Waters, J. A. (2000). "Achieving Innovation or the Holy Grail? Managing Knowledge or Managing Commitment?" International Journal of Technology Management 20, 819-838.

Wiklund, J., and D. Shepherd (2005). "Entrepreneurial Orientation and Small Business Performance: A Configurational Approach," Journal of Business Venturing 20(1), 71-91.

Zahra, S. A. (1996). "Technology Strategy and New Venture Performance: A Study of Corporate Sponsored and Independent Biotechnology Ventures," Journal of Business Venturing 11(4), 289-321.

Zahra, S. A., and G. George (1999). "Manufacturing Strategy and New Venture Performance: A Comparison of Independent and Corporate Ventures in the Biotechnology Industry," The Journal of High Technology Management Research 10(2), 313-345.

Zahra, S. A., R. D. Ireland, and M. A. Hitt (2000). "International Expansion by New Venture Firms: International Diversity, Mode of Market Entry, Technological Learning, and Performance," Academy of Management Journal 43(5), 925-950.

Zahra, S. A., D. O. Neubaum, and G. M. El-Hagrassey (2002). "Competitive Analysis and New Venture Performance: Understanding the Impact of Strategic Uncertainty and Venture Origin," Entrepreneurship Theory and Practice 27(1), 1-28.

Zirger, B. J., and M. A. Maidique (1990). "A Model of New Product Development: An Empirical Test," Management Science 36(7), 867-883. 